Marquette University

e-Publications@Marquette

College of Communication Faculty Research and

Publications

Communication, College of

$11-1-2017$

\title{
Does Ethical Orientation Matter? Determinants of Public Reaction to CSR Communication
}

Kyujin Shim

Singapore Management University

Myojung Chung

Nanyang Technological University

Young Kim

Marquette University, young.kim@marquette.edu

Accepted version. Public Relations Review, Vol. 43, No. 4 (November 2017): 817-828. DOI. (C) 2017

Elsevier. Used with permission. 


\section{e-Publications@Marquette}

\section{College of Communication Faculty Research and Publications/Department of Communication}

This paper is NOT THE PUBLISHED VERSION; but the author's final, peer-reviewed manuscript. The published version may be accessed by following the link in the citation below.

Public Relations Review, Vol. 43, No. 4 (2017): 817-828. DOI. This article is (C) Elsevier and permission has been granted for this version to appear in e-Publications@Marquette. Elsevier does not grant permission for this article to be further copied/distributed or hosted elsewhere without the express permission from Elsevier.

\section{Does ethical orientation matter? Determinants of public reaction to CSR communication}

Kim Young

College of Communication, Marquette University, Milwaukee WI

\section{Abstract}

Employing an experiment study $(N=256)$, this study examines how individuals ethical orientation (deontology vs. consequentialism) and CSR message frame (normative vs. strategic) influence corporate hypocrisy perception and negative communication intentions toward a given company. Findings demonstrate that deontological ethical orientation and strategic CSR frame induce stronger corporate hypocrisy perception and negative communication intention than do consequential ethical orientation and normative CSR frame. In addition, deontological ethical orientation moderated the effects of CSR frames on negative communication intention toward the company. Implications for both public relations scholarship and practices are discussed.

Keywords

Normative CSR, Strategic CSR, Corporate hypocrisy, Media frame, Ethical orientation 


\section{Introduction}

Today, Corporate Social Responsibility (hereafter CSR) is recognized as an indispensable component of business activities. Given its positive effects on business outcomes such as shaping employee commitment (Rettab, Brik, \& Mellahi, 2009), purchase intentions (Chu \& Lin, 2013), and brand sincerity (Ragas \& Roberts, 2009), approximately $90 \%$ of Fortune 500 companies consider CSR as an economic imperative in today's business world (Jahdi \& Acikdilli, 2009; Luo \& Bhattacharya, 2006; Neville, Bell, \& Mengüc, 2005; Sprinkle \& Maines, 2010).

However, a growing body of research has questioned whether CSR always leads to positive business outcomes (Dean, 2003 Sen \& Bhattacharya, 2001). In fact, public often perceives and react to CSR activities contrary to the companies' expectations. It has been suggested that stakeholder skepticism regarding CSR motives can be an important factor explaining why some CSR activities might be counter-productive (Du, Bhattacharya, \& Sen, 2010). The public often perceives CSR as self-interested behavior rather than pure philanthropic behavior, and such suspicion of CSR motives may diminish corporate reputation and induce negative attitudinal or behavioral reactions to the company (Bae \& Cameron, 2006). This skepticism or suspicion of CSR motives is closely linked to perceptions of corporate hypocrisy (Shim \& Yang, 2016).

Although perceptions of corporate hypocrisy can play a key role in determining the effectiveness of CSR activities (Yoon, Gürhan-Canli, \& Schwarz, 2006), there have been limited scholarly efforts to identify what factors form perception of corporate hypocrisy (Bae \& Cameron, 2006). To fill this void, this study aims to examine some factors that shape corporate hypocrisy perception. Specifically, this study first examines the roles of individual consumers' ethical orientation and mass media frames in shaping corporate hypocrisy perception. Then it investigates the interaction between the two factors on perceived corporate hypocrisy and subsequent attitudinal and behavioral intentions toward a given company.

To this end, this study employs a between-subjects experimental design in which media frames of CSR is manipulated (normative CSR vs. strategic CSR) and individuals' ethical orientation is measured. Through this experiment, we attempt to understand for whom specific CSR frames work or do not work, and why.

Getting involved with more fragmented and diverse stakeholders than ever, public relations today is going beyond a conventional framework. Thus, this study calls for a reframing in PR approaches with a focus on the factors causing negative impressions and/or dissolved relationships in corporate communication. Upon growing moral expectations for business activities, understanding the relationship between public's ethical orientations, media frame, and people's reaction to CSR activities will provide meaningful insights into effective CSR communication strategies for corporations.

\section{Literature review}

Normative CSR vs. strategic CSR

Companies engage in CSR activities with various motivations and goals. Since the early days of CSR research, motivations for CSR has been discussed extensively. For instance, Carroll $(1979,1991)$ 
categorized CSR activities into four types: economic, legal, ethical, and philanthropic. The author portrayed different types of CSR by using a pyramid model, implying that these four dimensions of CSR are all interconnected and do not stand alone. According to Carroll and Buchholtz (2003), companies should minimize cost and maximize profits to fulfill economic responsibilities, as economic performance is required by the society. Also, the companies are expected to obey the law to fulfill their legal responsibilities. In contrast, ethical responsibilities are not required but expected by society. The philanthropic responsibilities standing at the top of the pyramid aim to a good corporate citizen and improve the quality of life for the society.

Other scholars classified CSR motivations into the following four categories: strategic, political, altruistic motivation, and self-interest of management (Brammer \& Millington, 2005; Zhang, Zhu, Yue, \& Zhu, 2010). According to Saiia, Carroll, and Buchholtz (2003, p. 170), strategic is the practice of "doing good in order to do well." In this view, CSR appears to be consistent with the concept of the profit-maximizing model of a business. Political motivation is also in line with strategic motivation (Sánchez, 2000), as CSR can be used to maximize a company's political return on investment (ROI). However, some scholars interpret CSR as altruism; CSR is a practice of good citizenship and giving with nothing expected in return (Campbell, Gulas, \& Gruca, 1999; Cowton, 1987; Shaw \& Post, 1993). Another perspective of CSR is that executives utilize CSR to enhance their self-interests, not to maximize shareholder wealth (Atkinson \& Galaskiewicz, 1988; Galaskiewicz, 1997; Haley, 1991).

These different motivations of CSR can be re-classified into two broad categories: normative CSR vs. strategic CSR (Smith, 2003; Stolz, 2010). From normative CSR perspective, a company's CSR activities are basically rooted in altruistic or social causes. The company conducts CSR activities 'to fulfill its duty as a good citizen (Donaldson, 1982, p. 42)' and thus its most important aim is contributing to society's improvement and development (lankova, 2008; Maignan \& Ferrel, 2003; Stolz, 2010). In business reality, however, CSR is often utilized as a marketing tactic and a reputation booster aiming at further economic success (Schwepker \& Good, 2011). This is considered as strategic CSR, which mainly seeks long-term profits and efficiency via enhanced reputation and competitiveness (Juholin, 2004; Panapanaan, Linnanen, Karvonen, \& Phan, 2003; Stolz, 2010). In other words, strategic CSR is considered as "self-interested motives in CSR," as CSR mainly seeks long-term profit and efficiency through improved image and competitiveness (Juholin, 2004; Panapanaan et al., 2003) and riskmanaging practices aiming to keep the status quo for a stable business environment (Bondy, Matten, \& Moon, 2004).

\section{Corporate hypocrisy}

Corporate hypocrisy is defined as "the belief that a firm claims to be something that it is not (Wagner, Lutz, \& Weitz, 2009, p. 79)." It also refers to a lack of sincerity in a corporation's motives (Yoon et al., 2006) or self-interested motives (Bae \& Cameron, 2006). Previous studies have found that the attribution of suspicion is a useful framework to explain why corporate hypocrisy perception occurs (Jahdi \& Acikdilli, 2009). Suspicion refers to "a dynamic state in which the individual actively entertains multiple, plausibly rival hypotheses about the motives or genuineness of a person's behavior (Fein, 1996 , p. 1165)." In the CSR context, publics are likely to become suspicious of a private firm's motives when the company donates money to social causes, as the firm's foremost goal is to maximize profits (Bae \& Cameron, 2006; Friedman, 1970). In this case, CSR is likely to be considered as a conditional 
philanthropic activity. This perception of "strategic philanthropy (Godfrey, 2005)," in turn, can induce public suspicion about a company's hidden motives behind CSR (Dean, 2003).

Corporate hypocrisy has been the key concept that can explain why CSR outcomes might not be as positive as the firm initially expected (Sen \& Battacharya, 2001). For instance, Bae and Cameron (2006) suggest that perceived altruistic motives of CSR might lead to positive attitudes toward a company, whereas perceived self-interested motives for charitable giving might lead to negative attitudes toward the company. Alcañiz, Cáceres, and Pérez (2010) also argue that stakeholders' engagement with a company hinges on their judgement of underlying motives behind the company's CSR programs; if the CSR programs are seen as largely serving the company's own interests, the programs are unlikely to generate expected business outcomes. In contrast, CSR motives perceived as genuinely and sincerely intended to benefit the society generate supportive consumer attitudes and behaviors toward the company (Alcañiz et al., 2010).

Perceived corporate hypocrisy is important because it affects consumers' attitudes and behaviors toward a given company (Schwepker \& Good, 2011; Singh, Sanchez, \& Bosque, 2008; Wahlen, Pitts, \& Wong, 1991). Among various attitudinal and behavioral reactions following perceived corporate hypocrisy, this study highlights negative communication intention. People tend to create buzz regarding how they perceive CSR and CSR- related corporate issues. In the literature, the nature of discussant and opinion-generating publics was characterized as "dynamic and communicative (Vasquez \& Taylor, 2001, p. 149)," which brought to light the role of publics' "discursive interactions" in democratic society (Villa, 1992, p. 712). Price, Nir and Cappela (2006) described this feature of the communicative action as opinion-giving. Recent research also demonstrates that consumers not only passively consume information about the company but also proactively share that information via their personal and social networks (Kim, Grunig, \& Ni, 2010; Lovari, Kim, Vibber, \& Kim, 2005).

\section{Individual ethical orientation}

Regardless of the actual or ulterior motives behind each firm's CSR activities, ostensible motives of the CSR are to "benefit the community." Therefore, a company could self-claim that CSR endeavors are based on company morality. However, consumers' perceptions towards CSR activities might be different, being affected by individuals' ethical judgment of company's motives of CSR. In this regard, Sharp (1898) pointed out that people would come up with different assessments of moral issues, as they hold different ethical views on what is true virtue of ethics. Nevertheless, limited attention has been granted to audience traits that might moderate the perception of corporate hypocrisy and subsequent attitudinal and behavioral intentions.

To fill this void, this study examines the role of individuals' ethical orientation in shaping public perception of CSR. We assume that depending on individuals' ethical orientation, CSR may be perceived differently and thus induce different behavioral responses from consumers. This study focuses on two different ethical orientations: deontology vs. consequentialism. Rooted in the Kantian moral philosophy, deontology contends that an action is either moral or immoral in and of itself. For deontologists, consequences are not a determinant of ethical behavior (Kant, 1797Tanner et al., 2008). As such, deontology focuses on duty, which concurs with the assertion of Kant who believed that reason plays a key role in being moral (Anscombe, 1958; Kant, 1797; Tanner et al., 2008). In contrast, rooted in Utilitarian moral philosophy espoused by John Stuart Mill (1906), consequentialism proposes 
that ends justify means, and thus consequences are the basis for evaluating the morality of actions (Anscombe, 1958; Broad, 1930; Tanner et al., 2008). Mill contended that actions are right in proportion as they tend to promote happiness, and wrong as they tend to produce the reverse of happiness (Mill, $\underline{1906)}$.

Ample research has delved into varying effects of ethical orientation on ethical perceptions and behavioral responses (Barnett, Bass, \& Brown, 1994; Kim, 2003; Schlenker \& Forsyth, 1977) with special focus on two basic moral factors: relativism and idealism. Relativism is based on an assumption that some people are skeptical about applying universal rules of ethics in any ethical decision making process. Thus, people of relativism believe that best ethical decision making could be dependent on the diverse contexts rather than absolute ethical rules. On the other hand, idealism is based on the belief that only ethical actions lead to ideal consequences. However, relatively less idealistic people are more open to the interpretation of "ideal" consequences, as ethically driven actions sometimes might result in mixed outcomes.

Based on this approach of ethical relativism and idealism, this study assumes that deontological orientation tends to be more ethically idealistic and rigorous whereas consequentialist orientation tends to be more relativistic and pragmatic in CSR judgment. To elaborate, deontologists with low level of relativism and high level of absolutism would place strict standards for corporates' CSR motives and outcomes, thus would have more negative or doubtful perception of CSR motives. For example, when a company of bad reputation launches a CSR campaign to rehabilitate their damaged reputation or cover up the problems they have created, beneficial outcomes for the community might not credit CSR efforts as a moral act. Also, deontologists might be more willing to communicate negatively or cynically about the CSR efforts to align their perception of corporate hypocrisy and behavioral response to company's unethical motives. On the other hand, consequentialists would demonstrate high level of relativism and low level of idealism. Therefore, they are likely to have positive flexible thoughts about purposes of CSR activities. Further, considering the pragmatic inclination in consequentialists (Whalen, Pitts, \& Wong, 1991), it is assumed that even though they perceive corporate hypocrisy from selfinterested motives in CSR, they might not engage in negative communication about the company as long as outcome of CSR is beneficial for the society. Along this line, this study formulated the following hypotheses:

\section{H1}

Individuals' ethical orientation will be associated differently with negative reaction to CSR efforts and the company, as such

\section{H1a}

Deontological orientation will be associated with stronger corporate hypocrisy perception of CSR than will consequential orientation.

\section{H1b}

Deontological orientation will be associated with stronger negative communication intention than will consequential orientation. 
People's perception or evaluation of a company is often formed through exposure to mass media coverage of the company (Fombrun \& Van Riel, 2004). Ample research has noted that how media report about a company influences people's opinions and behaviors toward the company (Carroll \& McCombs, 2003; Coombs \& Holladay, 2007; Kim \& Kiousis, 2012; Sen \& Battacharya, 2001; Wagner et al., 2009). For instance, Coombs and Holladay (2007) asserted that the news media and the internet significantly affect the processing information about a crisis, thereby negatively alter attitudes toward a company. Carroll and McCombs (2003) also showed that there exist agenda-setting effects of business news on the public's images and opinions about corporations. According to Sen and Battacharya (2001), different news formats such as narrative vs. factual affect suspicion toward a company's ulterior motives regarding its CSR efforts.

Nevertheless, the role of mass media frame in shaping public reaction toward a company has not received much scholarly attention. Framing is one of the most representative ways that media messages give meaning to issues (Springer \& Harwood, 2015). For the past several decades, researchers have examined and demonstrated theoretical concept of framing as the powerful mechanisms helping define, solving problem, and shaping public opinion (An \& Gower, 2009; Entman, 2007; Fortunato, 2008; Matthes \& Kohring, 2008; Semetko \& Valkenburg, 2000). Through "selecting some aspects of the world and make them more salient than others" (Entman, 1993, p. 52), framing profoundly influences how people understand and evaluate a certain issue (Entman, 1993; Holt \& Major, 2010; lyengar, 1990).

In the CSR literature, only limited number of studies have explored the effects of media framing on people's attitudes toward CSR practices (David, Kline, \& Dai, 2005; Wang, 2007). For instance, Wang (2007) showed that a negatively framed news report regarding a target corporation will influence how people form judgments about the corporation's CSR activities. However, no study to date has examined how the motive of CSR is framed influence public perception and reaction toward CSR. This study takes a step to fill the gap by testing how media frame the motive of CSR affects perception of corporate hypocrisy and subsequent attitudinal and behavioral intentions toward the given company. Given that perceived altruistic motives of CSR lead to positive attitudes toward a company, whereas perceived self-interested motives of CSR lead to negative attitudes toward the company (Bae \& Cameron, 2006; Alcañiz et al., 2010), we propose the following hypotheses:

\section{$\mathrm{H} 2$}

Media framing will be associated differently with negative reaction to CSR efforts and the company, as such

\section{$\mathrm{H} 2 \mathrm{a}$}

Media messages with strategic CSR frame will be associated with stronger corporate hypocrisy perception than will media messages with normative CSR frame.

\section{$\mathrm{H} 2 \mathrm{~b}$}


Media messages with strategic CSR frame will be associated with stronger negative communication intention than will media messages with normative CSR frame.

\section{Interaction of ethical orientation and media frame}

When discussing the role of media frames in shaping public opinion and attitudes, scholars have illuminated existing beliefs, values, and knowledge as audience-level factors that may moderate media framing effects (Neuman, Just, \& Crigler, 1992; Rhee, 1997; Shen, 2004). For instance, Pan and Kosicki (1993) emphasized the interplay between news frames and the individual's knowledge as a key process to determine the ways of interpreting news texts. Rhee (1997) also suggested that pre-existing knowledge and belief system moderates the effects of news frames on individuals' interpretation of the issue.

Extending this line of research, this study focuses on audiences' ethical orientation as a potential moderator of media framing effects on public perception of CSR. In discussing publics' attitudes toward CSR activities, previous studies mainly focused on the overall "ethical consumers" who are sensitive to the company's ethical motives (Alcañiz et al., 2010). However, everyone has different levels of ethical orientations and thus we cannot generalize consumer ethics as a whole. Then how different ethical orientations influence individuals' reaction to media framing of CSR?

In sum, deontology and consequentialism are deemed the most striking contrast in people's ethical decision making and information processing (Tanner et al., 2008). Applied to the context of CSR, deontology is in line with normative CSR and consequentialism is in line with strategic CSR. This study predicts that these contrasting ethical orientations may have impact on the way people react to different media frames of CSR activities. More specifically, depending on ethical orientation, individual audiences' processing of CSR frames can be different. Accordingly, corporate hypocrisy perception as well as negative communication intention toward a company may also vary. Nevertheless, no research up to date has empirically examined the interaction between media frame and ethical orientation on perceived corporate hypocrisy and subsequent attitudinal and behavioral intentions. In light of the limited findings in the literature, this study proposes the following exploratory research question:

RQ: How do media framing of CSR and ethical orientation interact in influencing (a) corporate hypocrisy perception and (b) negative communication intention toward a company?

\section{Method}

This study employed a between-subjects experimental design to examine the impacts of individual ethical orientation and media framing of CSR activities on perceived corporate hypocrisy and negative communication intention.

\section{Participants}

After conducting pre-test $(N=143)$, participants living in South Korea were recruited from an online panel managed by a leading survey firm (macromill: Embrain) known for its expertise in survey sampling. Embrain is the biggest Asian Panel Network firm with a diverse subject pool, maintaining more than 1.8 million registered panel members (embrain.com, 2016). For this study, Embrain 
recruited the participants based on different proportion of gender and population (i.e., quota sampling method). Participants in the survey firm's online panel agreed to a standard set of credits for participating in this online experiment. The total sample size was 256 (female $=49.2 \%$, male $=50.8 \%$ ). Participants ranged in age from 21 to 69. Among the participants, $11.3 \%(n=29)$ had some postgraduate or professional or higher level education, $55.5 \%(n=142)$ had two year associate or four year college degree, $28.1 \%(n=72)$ had high school graduate, and $5.1 \%(n=13)$ had less than high school education degree.

\section{Data collection procedure}

Participants were informed by the consent form about the purpose, procedure, statement of privacy, and benefits. They then indicated their agreement with what they would do to answer after reading a vignette about a hypothetical company named Human-Tech facing an ethical dilemma in its global business practice. After reading the vignette, subjects were asked to answer questions that were designed to measure their ethical orientation - deontological or consequential.

Participants were randomly assigned to one of the two conditions to read either of two differently framed news articles: normative CSR frame and strategic CSR frame. After reading the articles, they answered questions about how they perceive the company's motives and outcomes related to the CSR activities, their perceived level of corporate hypocrisy and communication intentions regarding the firm. Demographics were measured at the end of the questionnaire. When the questionnaire was completed, subjects were debriefed that the news story they read was fictitious and created only for this study.

Since the original questionnaire was constructed in English first, the questionnaire was translated into Korean for an experiment in Korea. To check the reliability of the translation, a Korean professional living in Seoul, who had received an advanced degree from a U.S. institution, back-translated the Korean questionnaire into English. The translation showed a high level of consistency. A few questions that were back-translated in slightly different ways were re-analyzed and adjusted.

\section{Stimuli}

The stimuli used in this study begin with a brief introductory statement about a fictitious pharmaceutical company, GLOMEDS that produces and sells generics, vaccines and medications for fatal diseases in the global market. Subjects also read information about the company's CSR activities as well as about debate on the high drug price and patent issues. Then followed a news article and an editorial from Corporate Watch, an independent nonprofit research and publishing group. The CSR frame in the news article and editorial was manipulated in two ways: the normative CSR frame highlights the company's altruistic motives and outcomes for the communities' well-being and development. On the contrary, the strategic CSR frame sheds lights on self-interested motives and outcomes for the company's profits and marketing. To increase the authenticity of the language and tone of the stories, an experienced journalist created the news story and editorial. The amount (around 200 words) and structure of the news content was kept the same across the conditions.

For the news articles with different CSR frames, this study chose the topic of CSR by a transnational pharmaceutical company for the following reasons. Business ethics and social responsibility can never 
be overemphasized for transnational health companies, as the health business is closely related to basic human rights and dignity (Doh \& Guay, 2006; Vasella, 2003; Zoller, 2005). At the same time, transnational health companies have major concerns in third world markets regarding negotiated price reductions and execution of non-patented drugs (Homedes \& Ugalde, 2006; Shim, 2014). Therefore, transnational health industry provides an apt context in which normative CSR and strategic CSR can be discussed.

\section{Measures}

Independent variable - ethical orientation

This study measures individuals' I ethical orientation using two dimensions: deontological vs. consequential. Ethical orientation was measured by 14 items, which were adopted from Reidenbach and Robin (1988) and modified for this study's global business context. To measure deontological tendency, participants answered seven items $(M=3.98, S D=0.62$, Cronbach's $\alpha=0.88$, e.g., "I feel the company HUMAN-TECH is a bad business even though it continues its success"). To measure individual subjects' consequential tendency, other seven items were used $(M=2.74, S D=0.88, \alpha=0.78$, e.g., "I believe it is more important for a business to be concerned with successful outcomes than the means to achieve those outcomes").

\section{Dependent variable - corporate hypocrisy perception and negative communication intention}

Corporate hypocrisy was conceptualized as the ethical attribution of misalignment between selfinterestedness and altruism in corporate philanthropic endeavors. Three items adopted from $\underline{\text { Wagner }}$ et al. (2009) were used to measure perceived corporate hypocrisy $(M=3.15, S D=0.86, \alpha=0.90$, e.g., "GLOMEDS pretends to be something that it is not").

To measure another dependent variable, negative communication intention, this study adopted six items from Kim and Rhee's (2011) megaphoning scales and Moon (2011)'s public communication behaviors scales $(M=3.00, S D=0.75, \alpha=0.90$, e.g., "I would distribute some negative articles or reports about the company's social responsibility to my friends or people that I know"). All of these items were measured on a five-point Likert scale ranging from 1 (strongly disagree) to 5 (strongly agree).

\section{Results}

\section{Manipulation check}

To confirm that the experimental manipulations performed as intended, subjects were asked how they perceived the motives and outcomes of the CSR activity mentioned in the news article. The following four questions were used on a 5-point Likert scale: "I think the above article insinuates that the company's self-interested motives to boost earnings and image in its CSR campaign," "I think the above article insinuates that the company's CSR campaign resulted in boosting company's earnings and brand image," "I think the above article insinuates the company's altruistic motives for helping patients and local community in its CSR campaign," "I think above article insinuates that patients and the local community received a great deal of benefits from the company's CSR campaign." The former two questions measured perceived strategic aspect of the CSR activities $(M=3.60, S D=0.81, r=0.24$, 
$p<0.001)$ and the latter two questions measured perceived normative aspect of the CSR activities $(M=3.31, S D=0.92, r=0.38, p<0.001)$. Independent-samples $t$-test revealed that the manipulation was successful; strategic perception was significantly higher for the strategic CSR frame article, $t(254)=3.56, p<0.001$, and normative perception was significantly higher for the normative CSR frame article, $t(254)=5.34, p<0.001$.

\section{The impacts of ethical orientation and CSR news frame on the CSR outcomes}

Since multiple items were used to measure main variables in this study, exploratory factor analyses (EFA) and confirmatory factor analysis (CFA) were run to check dimensionality of the measures and the covariance items (i.e., composite reliability and construct validity). Using STATA 13 statistical software program, EFA was conducted by oblique rotation methods (i.e., PROMAX) based on several criteria for extracting factors, including eigenvalue-greater-than 1 , loadings in the 0.40 range and above as substantial, and percentage of variance criterion (i.e., $60 \%$ of the total variance) (Netemeyer, Bearden, \& Sharma, 2003). As a result, one item from consequentialism orientation was deleted (e.g., CT 4) because it did not meet the minimal level for interpretation of structure (i.e., below 0.40 ).

Based on EFA results, CFA using AMOS 22 software program was conducted to analyze and select the best measurement items for each construct. The initial CFA analysis indicates that there were two measurement items (e.g., CT3 and 7) for consequentialism orientation in a violation of construct validity due to significantly low level standardized loading $(B<0.50)$ and average variance extracted (AVE < 0.50) (Hair, Black, Babin, \& Anderson, 2009). The two items were deleted, and CFA was then run again. Construct validity (standardized loading estimate $>0.50$, convergent validity: AVE $>0.50$, discriminant validity: AVE > average shared variance: ASV), and composite reliability $(C R>0.70)$ were successfully established in all measurement items (Hair et al., 2009). The final CFA model goodness-of-

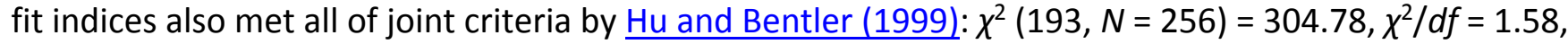
$p=0.00$, Comparative Fit Index $(\mathrm{CFI})=0.96$, Standardized Root Mean Square Residual $(\mathrm{SRMR})=0.04$, Root Mean Square Error of Approximation (RMSEA) = 0.05 (See Table 1).

Table 1 . Results of composite reliability and construct validity $(N=256)$.

\begin{tabular}{|c|c|c|c|c|c|c|}
\hline $\begin{array}{c}\text { Latent } \\
\text { Variable }\end{array}$ & Measurement Items & $\begin{array}{l}\text { Standardized } \\
\text { Loading } \\
\text { Estimate }(6)\end{array}$ & $\begin{array}{c}\text { Explained } \\
\text { Variance } \\
\left(R^{2}\right)\end{array}$ & $\begin{array}{l}\text { Composite } \\
\text { Reliability } \\
\text { (CR) }\end{array}$ & $\begin{array}{l}\text { Average } \\
\text { Variance } \\
\text { Extracted } \\
\text { (AVE) }\end{array}$ & $\begin{array}{c}\text { Average } \\
\text { Shared } \\
\text { Variance } \\
\text { (ASV) }\end{array}$ \\
\hline \multirow{2}{*}{$\begin{array}{l}\text { Deontological } \\
\text { Orientation } \\
\text { (DO) }\end{array}$} & $\begin{array}{l}\text { DO } 1 . \text { I feel the } \\
\text { company HUMAN- } \\
\text { TECH is a bad business } \\
\text { even though it } \\
\text { continues its success. }\end{array}$ & 0.80 & 0.63 & \multirow{2}{*}{0.87} & \multirow{2}{*}{0.50} & \multirow{2}{*}{0.17} \\
\hline & $\begin{array}{l}\text { DO } 2 . \text { I believe the } \\
\text { successful outcomes } \\
\text { cannot justify the } \\
\text { means to those } \\
\text { outcomes. }\end{array}$ & 0.70 & 0.50 & & & \\
\hline
\end{tabular}




\section{Latent Variable}

Measurement Items

Standardized Explained Loading

Estimate ( 6 )
Variance

$\left(R^{2}\right)$
Average Average

Variance Shared

Extracted Variance

(AVE) (ASV)

DO 3. I believe that

following moral

obligations in

managerial process is

$\begin{array}{ll}0.50 & 0.23\end{array}$

the most important

aspect by which to

judge a corporation.

DO 4. Based on my

idea of fairness, the

Company HUMAN-

0.82

0.66

TECH is an unethical

business.

DO 5. I think this

company is unethical

because it has little

0.82

0.68

ethical concerns in

labor rights.

DO 6. I think the

company should abide

by law in order to be

an ethical company

rather than to avoid

penalty.

DO 7. Although the company did not

directly hire the

overseas labor workers, the company should be responsible for the poor working conditions.

CT1. I feel the company HUMAN-TECH has little reason to worry about Consequentialism the critics of its

$0.87 \quad 0.75$

(CR)

management as long as

$0.85 \quad 0.59$

0.17

it continues its success.

CT 2. I believe it is

$\begin{array}{lll}\text { more important for a } & 0.83 & 0.69\end{array}$

business to be 


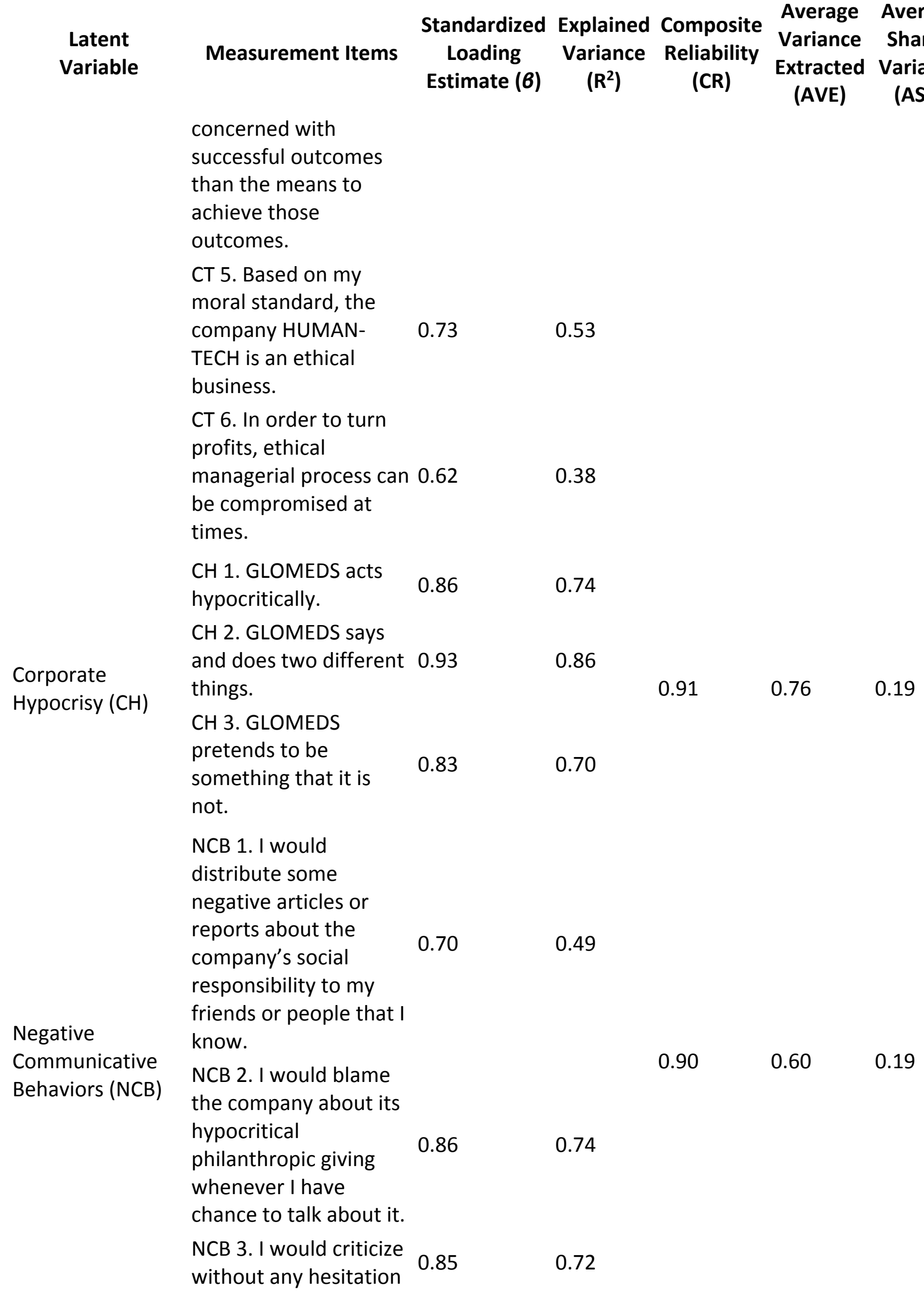




\section{Latent Variable}

\section{Measurement Items}
Standardized
Loading
Estimate (b)
Explained
Variance
$\left(\mathbf{R}^{2}\right)$

Average Average

Variance Shared

Extracted Variance

(AVE) (ASV)

how the company puts

its business first, rather

than patients.

NCB 4. I would correct

someone who

overestimates the

company's

$\begin{array}{ll}0.65 & 0.41\end{array}$

philanthropic giving

during any

conversation about it.

NCB 5. If there is

someone who says a

good word for the

company's social

responsibility, I cannot $0.79 \quad 0.63$

help but give him the

opposite

aspect/perspective of

it.

NCB 6. I would support

negative aspects about

the company's social

0.79

0.63

responsibility that

others provide.

Note: $\mathrm{CT} 3,4$, and 7 were deleted due to violation of construct validity. Construct validity (standardized loading estimate > .50, convergent validity: AVE > .50, discriminant validity: AVE > ASV), and composite reliability $(C R>.70)$ were successfully established (Hair, Black, Babin, \& Anderson, 2010). CAPS Confirmatory Factor Analysis (CFA) model goodness-of-fit indices met all of the joint criteria by $\mathrm{Hu}$ and Bentler (1999): $\chi^{2}(193$, $N=256)=304.78, \chi^{2} / d f=1.58, p=0.00$, Comparative Fit Index $(\mathrm{CFI})=0.96$, Standardized Root Mean Square Residual $(S R M R)=0.04$, Root Mean Square Error of Approximation $($ RMSEA $)=0.05$.

To test hypotheses and answer our research question, a series of multiple ordinary least squares (OLS) regression analyses were conducted in STATA 13 statistical software program. Prior to running multiple OLS regression analyses, continuous independent variables, including deontological orientation and consequentialism orientation, were centered to obtain meaningful interpretation and eliminate nonessential multicollinearity because the regression models included interaction terms. Cohen et al. (2003) recommended that "continuous predictors be centered before being entered into regression analyses containing interactions" (p. 266). After centering procedure, two interaction terms were created and named as framing*deontological and framing*consequentialism. Assumptions were checked to ensure that there was no violation. The variance inflation factor (VIF) and tolerance (T) showed that there was not a violation for multicollinearity in all independent variables (i.e., VIF of each 
variable $<10$ and T of each variable $>0.10)$. Regarding heteroscedasticity, Breusch-Pagan/CookWeisberg test was conducted and revealed that there was no violation of homoscedasticity as fitted values of hypocrisy, $\chi^{2}(1)=0.38, p=0.38($ step 1$)$ and $\chi^{2}(1)=0.29, p=1.13($ step 2$)$ and fitted values of negative communication intention, $\chi^{2}(1)=0.03, p=0.86($ step 1$)$ and $\chi^{2}(1)=1.13, p=0.29($ step 2$)$ (See Table 2).

Table 2. OLS regression analyses for the associations between ethical orientation and negative CSR outcomes.

\section{Variables}

Step 1

Constant

Deontological Orientation

Consequentialism Orientation

Message Framing

(Strategic: 1, Normative: 0)

$R^{2}$

F

Step 2

Constant

Deontological Orientation

Consequentialism Orientation

Message Framing

(Strategic: 1, Normative: 0)
Hypocrisy (HY) Negative Megaphoning (NM)

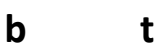

b $\mathbf{t}$

\begin{tabular}{|c|c|c|c|}
\hline Message Framing x Deontological Orientation & $0.34 \quad 1.59$ & 0.37 & $2.06^{*}$ \\
\hline Message Framing $x$ Consequentialism Orientation & $-0.29-1.71$ & -0.06 & -0.40 \\
\hline$\Delta R^{2}$ & 0.05 & 0.04 & \\
\hline$R^{2}$ & 0.20 & 0.12 & \\
\hline$F$ & $12.13 * * *$ & $4.89 * * *$ & \\
\hline
\end{tabular}

Note: ${ }^{* *} p<0.001,{ }^{* *} p<0.01,{ }^{*} p<0.05$. All independent variables are not in a violation of multicollinearity (i.e., Variance Inflation Factor of each variable $<10$ and Tolerance of each variable $<0.10$ ). Breusch-Pagan/CookWeisberg test revealed that there was no heteroscedasticity.

To run multiple OLS regression analyses, CSR framing factors were recoded as dichotomous variable (e.g., strategic CSR: 1, normative CSR: 0). Independent variables such as deontological orientation, consequentialism orientation, and media framing in the model accounted for a significant portion of the variance in corporate hypocrisy, $R^{2}=0.15, F(3,252)=14.33, p<0.001$ and negative communication intention, $R^{2}=0.08, F(3,252)=6.95, p<0.001$. As expected, deontological orientation was associated with corporate hypocrisy and negative communication intention than consequential orientation. The results indicate that one unit change in deontological orientation results in an increase of 0.12 in corporate hypocrisy $(\mathrm{H} 1 \mathrm{a}: \mathrm{b}=0.12, \mathrm{t}=2.70)$ and an increase of 0.20 in negative communication intention ( $\mathrm{H} 1 \mathrm{~b}: \mathrm{b}=0.20, t=2.15)$, controlling for the effects of other independent variables in the 
models. The $t$ statistics of deontological orientation were statistically significant, but consequential orientation coefficients did not make significant difference in corporate hypocrisy perception and negative communication intention. Therefore, $\mathrm{H} 1 \mathrm{a}$ and $\mathrm{H} 1 \mathrm{~b}$ were supported (See Table 2).

Regarding $\mathrm{H} 2$, strategic CSR frame was associated with corporate hypocrisy perception and negative communication intention more than normative CSR frame The results showed that one unit change in the CSR frame (i.e., strategic frame) results in an increase of 0.58 in perceived corporate hypocrisy $(b=0.58, t=5.95)$ and an increase of 0.34 in negative communication intention $(b=0.34, t=4.01)$. To estimate how different effects of strategic framing compared to normative CSR framing have on negative outcomes, corporate hypocrisy perception and negative communication intention, coefficients of all independent variable were applied to the multiple regression equation, $Y=a+b_{1} * X_{1}+b_{2} * X_{2}+\ldots+b_{p} * X_{p}$. For instance, predicted value of strategic CSR frame on corporate hypocrisy perception $\left(\hat{Y}_{\text {strategic-hypocrisy }}=1.44+(0.28) *\right.$ deontological orientation $+(0.12) *$ consequential orientation $+(0.58) * 1$ ) was compared with predicted value of normative CSR frame on corporate hypocrisy perception $\left(\hat{Y}_{\text {normative-hypocrisy }}=1.44+(0.28) *\right.$ deontological orientation $+(0.12) *$ consequential orientation $\left.+(0.58)^{*} 0\right)$. Similarly, the predicted values of strategic and normative CSR frames on negative communication intention were also compared by applying all coefficients to the multiple regression equation. As results, the differences of predicted values (corporate hypocrisy: $t=2.02$ and negative communication intention: $\mathrm{t}=2.12$ ) were statistically significant at $p<0.05$. Therefore, $\mathrm{H} 2 \mathrm{a}$ and $\mathrm{H} 2 \mathrm{~b}$ were supported as well.

To answer RQ, two interaction terms, framing*deontology and framing*consequentialism, were added into the regression models, and all independent variables in the models accounted for a significant portion of variance in corporate hypocrisy perception, $R^{2}=0.20, F(3,252)=12.13, p<0.001$ and $12 \%$ of the variance in negative communication intention, $R^{2}=0.12, F(3,252)=4.89, p<0.001$ (Step 2). However, one interaction factor, framing*deontological, was statistically significant only in negative communication intention $(b=0.37, t=2.06)$, but not in perceived corporate hypocrisy. As Fig. 1 shows, those who have deontological orientation are more likely to have negative communication intention when they read media messages with strategic CSR frame. Hence, the positive association between strategic CSR frame and negative communication intention will be stronger for individuals with deontological orientation. 


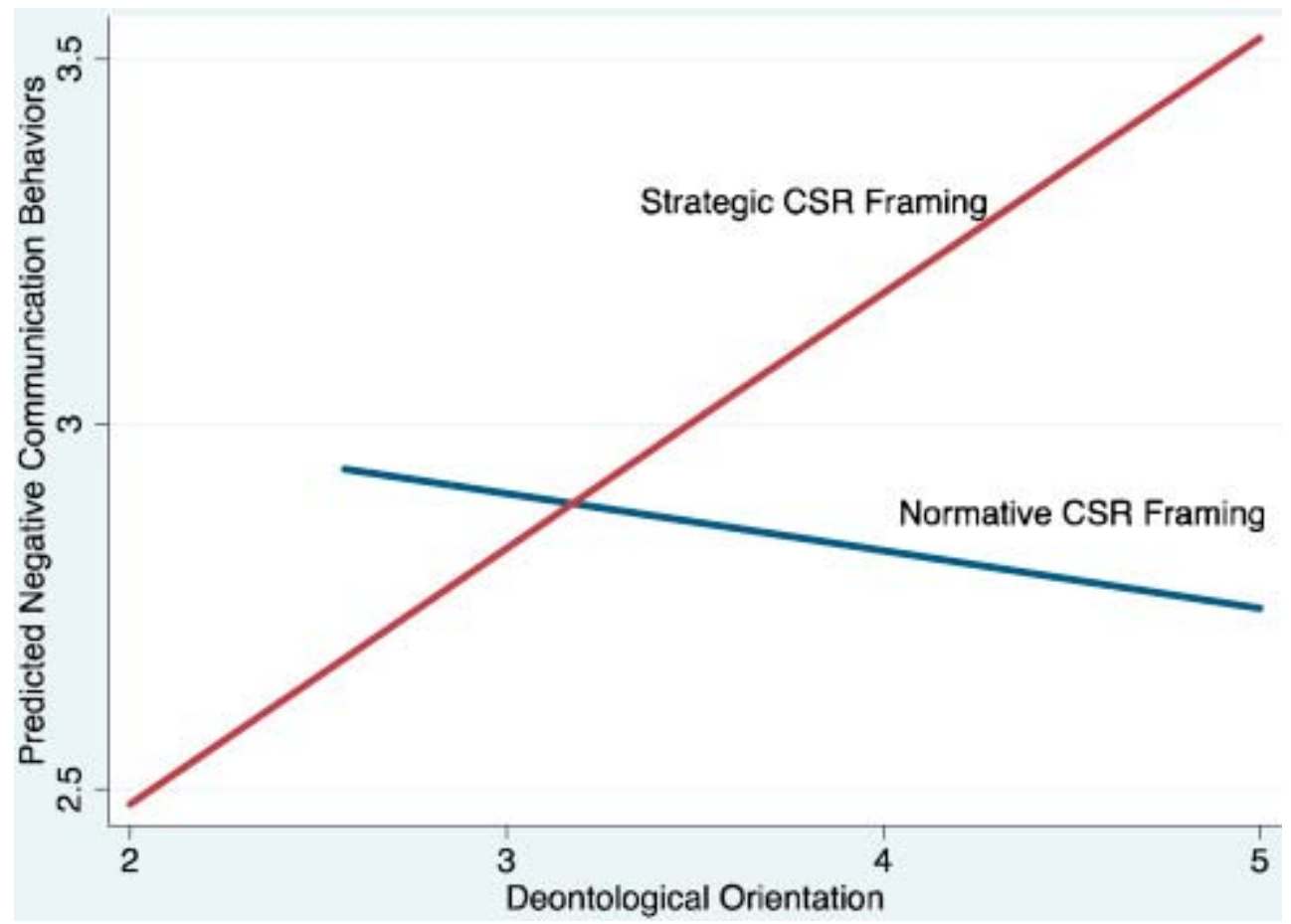

Fig. 1. Linear prediction lines for interaction relationships between deontological orientation and media CSR framing.

The other interaction term, framing*consequentialism, did not yield significant result in perceived corporate hypocrisy and negative communication intention. When controlling the effects of interaction factors with the CSR frame and ethical orientation, deontological orientation was no longer statistically significant for corporate hypocrisy perception and negative communication intention, while consequential orientation was positively associated with perceived corporate hypocrisy $(b=0.28$, $t=2.17$ ), but not with negative communication intention. The effects of the strategic CSR frame were consistent as a significant factor associating with corporate hypocrisy perception $(b=0.59, t=6.11)$ and negative communication intention $(b=0.34, t=4.07)$, controlling for the effects of interaction terms. When comparing with the effects of the normative CSR frame, the effects of the strategic CSR frame were statistically significant in corporate hypocrisy perception $(t=2.24)$ and negative communication intention $(\mathrm{t}=2.86)$ at $p<0.05$ as well (See Table 2 ).

\section{Discussion}

The main goal of this study was to explore factors that determine public perception of and reactions to CSR activities. More specifically, it investigated how media framing of CSR (normative vs. strategic) interacts with individuals' ethical orientation (deontology vs. consequentialism) in influencing corporate hypocrisy perception and subsequent attitudinal and behavioral intentions. The main ideas were that (a) media framing of CSR may influence people's perception of the CSR activities, but (b) the corporate hypocrisy perception and subsequent attitudes may vary depending on individuals' ethical orientation.

The findings show that the way media depict CSR affect how people perceive and evaluate CSR activities and the company itself. In the experiment, subjects who saw a news story with a strategic 
CSR frame demonstrated stronger corporate hypocrisy perception and negative communication intentions toward the company. It offers continued support for previous research that elucidates the power of media frames on people's message processing. The findings also demonstrate that individuals' ethical orientation have impact on perceived corporate hypocrisy and negative communication intention regarding a firm's CSR efforts.

The key finding of this study indicates that individuals' ethical orientation moderates the effect of media frame on people's perception and evaluation of CSR activities. Depending on their individual ethical orientation, people react to the media-framed CSR activities differently. For instance, the impact of strategic CSR frame on negative communication intention regarding a given company was stronger among people with deontological ethical orientation than among people with consequential ethical orientation.

This finding is in line with previous literature asserting that the characteristics of the audience play an important role in determining media effects (Mastro, 2009; Reid, Giles, \& Harwood, 2005). Although growing scholarly attention has been paid to individual characteristics such as gender, age, education level, political orientation, and cultural orientation as factors affecting attitudes toward CSR activities (Maignan \& Ferrell, 2003; Paul, Zalka, Downes, Perry, \& Friday, 1997; Sen \& Bhattacharya, 2001;

Wagner et al., 2009), the relationship between individuals' ethical orientation and their reaction to CSR has not been explored. This study filled the gap by demonstrating that individual consumers' ethical orientation moderates the effects of media frames on people's perception of CSR activities.

This study carries meaningful implications for public relations scholars and practitioners. First, it reconfirms the importance of media relations in CSR communication given the persisting impact of media frames. Second, by illuminating the important role of audiences' ethical orientation, this study highlights the need to carefully analyze ethical sentiment of the target audience when implementing and communicating CSR efforts. As today's public relations involve more fragmented and diverse stakeholders than ever, this in-depth understanding of stakeholders is an indispensable step to go beyond a conventional framework.

While this study offers interesting findings and implications, some limitations of the study need to be discussed for future research. First, this study examined the effects of media frame and ethical orientation on corporate hypocrisy perception and negative communication intention for a single topic, which might limit the findings to a specific context. Future research would benefit from using a broader basis of stimuli to see any overarching pattern of ethical orientation effects and media framing effects. Operationalization or measurement of some variables also could have received more consideration. For instance, although this study formulated statistically acceptable measurements for individual ethical orientation and negative communication intention, a more comprehensive operationalization of the concepts can benefit future research. Lastly, the analysis of this study was confined to a single country. Given the increasingly global nature of public relations, future research examining cultural or national variations in relation to the role of ethical orientation in CSR communication will greatly expand the scope of this line of research. 


\section{References}

Alcañiz, E. B., Cáceres, R. C., \& Pérez, R. C. (2010). Alliances between brands and social causes: The influence of company credibility on social responsibility image. Journal of Business Ethics, 96(2), 169-186.

An, S. K., \& Gower, K. K. (2009). How do the news media frame crises? A content analysis of crisis news coverage. Public Relations Review, 35(2), 107-112.

Anscombe, G. E. M. (1958). Modern moral philosophy. Philosophy, 33(124), 1-19.

Atkinson, L., \& Galaskiewicz, J. (1988). Stock ownership and company contributions to charity. Administrative Science Quarterly, 82-100.

Bae, J., \& Cameron, G. T. (2006). Conditioning effect of prior reputation on perception of corporate giving. Public Relations Review, 32, 144-150.

Barnett, T., Bass, K., \& Brown, G. (1994). Ethical ideology and ethical judgment regarding ethical issues in business. Journal of Business Ethics, 13(6), 469-480.

Bondy, K., Matten, D., \& Moon, J. (2004). The adoption of voluntary codes of conduct in MNCs: A three-country comparative study. Business and Society Review, 109(4), 449-477.

Brammer, S., \& Millington, A. (2005). Corporate reputation and philanthropy: An empirical analysis. Journal of Business Ethics, 61(1), 29-44.

Broad, C. D. (1930). Five types of ethical theory. New York: Harcourt, Brace and Co.

Campbell, L., Gulas, C. S., \& Gruca, T. S. (1999). Corporate giving behavior and decision-maker social consciousness. Journal of Business Ethics, 19(4), 375-383.

Carroll, A. B. (1979). A three-dimensional conceptual model of corporate performance. Academy of Management Review, 4(4), 497-505.

Carroll, A. B. (1991). The pyramid of corporate social responsibility. Toward the moral management of organizational stakeholders. Business Horizons, 34(4), 39-48.

Carroll, A. B., \& Buchholtz, A. K. (2003). Business and society. Ethics and stakeholder management (5th ed.). Mason, $\mathrm{OH}$ : Thomson South-Western.

Carroll, C. E., \& McCombs, M. (2003). Agenda-setting effects of business news on the public's images and opinions about major corporations. Corporate Reputation Review, 6(1), 36-46.

Chu, S. C., \& Lin, J. S. (2013). Consumers' perception of corporate social responsibility in the United States and China: A study of female cosmetics consumers. International Journal of Strategic Communication, 7(1), 43-64.

Cohen, J., Cohen, P., West, S. G., \& Aiken, L. S. (2003). Applied multiple correlation/regression analysis for the behavioral sciences. UK: Taylor \& Francis.

Coombs, W. T., \& Holladay, S. J. (2007). It's not just PR: Public relations in society. Malden, MA: Blackwell Publishing.

Cowton, C. J. (1987). Corporate philanthropy in the United Kingdom. Journal of Business Ethics, 6(7), 553-558.

David, P., Kline, S., \& Dai, Y. (2005). Corporate social responsibility practices, corporate identity, and purchase intention: a dual-process model. Journal of Public Relations Research, 17, 291-313.

Dean, D. H. (2003). Consumer perception of corporate donations effects of company reputation for social responsibility and type of donation. Journal of Advertising, 32(4), 91-102.

Doh, J. P., \& Guay, T. R. (2006). Corporate social responsibility, public policy, and NGO activism in Europe and the United States: An institutional-stakeholder perspective. Journal of Management Studies, 43(1), 47-73.

Donaldson, T. (1982). Corporations and morality. Englewood Cliffs, NJ: Prentice-Hall. 
Du, S., Bhattacharya, C. B., \& Sen, S. (2010). Maximizing business returns to corporate social responsibility (CSR): The role of CSR communication. International Journal of Management Reviews, 12(1), 8-19.

Entman, R. (1993). Framing: Towards clarification of a fractured paradigm. Journal of Communication, $43,51-58$.

Entman, R. M. (2007). Framing bias: Media in the distribution of power. Journal of Communication, 57(1), 163-173.

Fein, S. (1996). Effects of suspicion on attributional thinking and the correspondence bias. Journal of Personality and Social Psychology, 70, 1164-1184.

Fombrun, C. J., \& Van Riel, C. B. (2004). Fame \& fortune: how successful companies build winning reputations. FT Press.

Fortunato, J. A. (2008). Restoring a reputation: The Duke University lacrosse scandal. Public Relations Review, 34(2), 116-123.

Friedman, M. (1970). The social responsibility of business is to increase its profits. New York, 122-124.

Galaskiewicz, J. (1997). An urban grants economy revisited: Corporate charitable contributions in the Twin Cities, 1979-81, 1987-89. Administrative Science Quarterly, 445-471.

Godfrey, P. C. (2005). The relationship between corporate philanthropy and shareholder wealth: A risk management perspective. Academy of Management Review, 30(4), 777-798.

Hair, J. F., Black, W. C., Babin, B. J., \& Anderson, R. E. (2010). Multivariate data analysis (7th ed.). Upper Saddle River, NJ: Prentice Hall.

Haley, U. C. (1991). Corporate contributions as managerial masques: Reframing corporate contributions as strategies to influence society. Journal of Management Studies, 28(5), 485510.

Holt, L. F., \& Major, L. H. (2010). Frame and blame: an analysis of how national and local newspapers framed the Jena six controversy. Journalism and Mass Communications Quarterly, 87(3/4), 582597.

Homedes, N., \& Ugalde, A.1 (2006). Improving access to pharmaceuticals in Brazil and Argentina. Health Policy and Planning, 21(2), 123-131.

Hu, L., \& Bentler, P. M. (1999). Cutoff criteria for fit indexes in covariance structure analysis: Conventional criteria versus new alternatives. Structural Equation Modeling. A Multidisciplinary Journal, 6(1), 1-55.

lankova, E. A. (2008). From corporate paternalism to corporate social responsibility in post-communist Europe. Journal of Corporate Citizenship, 29, 75-89.

lyengar, S. (1990). Framing responsibility for political issues: The case of poverty. Political Behavior, 12, 19-40.

Jahdi, K. S., \& Acikdilli, G. (2009). Marketing communications and corporate social responsibility (CSR): Marriage of convenience or shotgun wedding? Journal of Business Ethics, 88(1), 103-113.

Juholin, E. (2004). For business or the good of all? A Finnish approach to corporate social responsibility. Corporate Governance, 4(3), 20-31.

Kant, I. (1797). The metaphysical principles of virtue, trans. Indianapolis: Hackett.

Kim, J. N., Grunig, J. E., \& Ni, L. (2010). Reconceptualizing the communicative action of publics: Acquisition, selection, and transmission of information in problematic situations. International Journal of Strategic Communication, 4(2), 126-154.

Kim, J. Y., \& Kiousis, S. (2012). The role of affect in agenda building for public relation: Implecations for public relations outcomes. Journalism \& Mass Communication Quarterly, 89(4), 657-676. 
Kim, J. N., \& Rhee, Y. (2011). Strategic thinking about employee communication behavior (ECB) in public relations: Testing the models of megaphoning and scouting effects in Korea. Journal of Public Relations Research, 23(3), 243-268.

Kim, Y. (2003). Ethical standards and ideology among Korean public relations practitioners. Journal of Business Ethics, 42(3), 209-223. http://dx.doi.org/10.1023/ a:1022281507601.

Lovari, A., Kim, S., Vibber, K., \& Kim, J. (2005). Digitisation's impacts on publics: Public knowledge and civic conversation. Institutional Knowledge at Singapore Management University.

Luo, X., \& Bhattacharya, C. B. (2006). Corporate social responsibility, customer satisfaction, and market value. Journal of Marketing, 70(4), 1-18.

Maignan, I., \& Ferrell, O. C. (2003). Nature of corporate responsibilities: Perspectives from American, French, and German consumers. Journal of Business Research, 56(1), 55-67.

Mastro, D. (2009). Effects of racial and ethnic stereotyping. In M. B. Oliver, \& J. Bryant (Eds.), Media Effects: Advances in Theory and Research (pp. 325-341). New York, NY: Routledge.

Matthes, J., \& Kohring, M. (2008). The content analysis of media frames: Toward improving reliability and validity. Journal of Communication, 58(2), 258-279.

Mill, J. S. (1906). Utilitarianism. Chicago, IL: University of Chicago Press.

Moon, B. (2011). Development and validation of scales to measure public's communicative act and negative organization-public relationship. (Unpublished doctoral dissertation). Hankuk University of Foreign Studies: South Korea.

Netemeyer, R. G., Bearden, W. O., \& Sharma, S. (2003). Scaling procedures: Issues and applications. Thousand Oaks, CA: Sage Publication, Inc.

Neuman, R. W., Just, M. R., \& Crigler, A. N. (1992). Common knowledge: News and the construction of political meaning. Chicago: University of Chicago Press.

Neville, B. A., Bell, S. J., \& Mengüç, B. (2005). Corporate reputation, stakeholders and the social performance - financial performance relationship. European Journal of Marketing, 39(9/10), 1184-1198. http://dx.doi.org/10.1108/03090560510610798.

Pan, Z., \& Kosicki, G. M. (1993). Framing analysis: An approach to news discourse. Political Communication, 10(1), 55-75.

Panapanaan, V. M., Linnanen, L., Karvonen, M. M., \& Phan, V. T. (2003). Roadmapping corporate social responsibility in Finnish companies. Journal of Business Ethics, 44(2/3), 133-148.

Paul, K., Zalka, L. M., Downes, M., Perry, S., \& Friday, S. (1997). US consumer sensitivity to corporate social performance development of a scale. Business \& Society, 36(4), 408-418.

Price, V., Nir, L., \& Cappella, J. N. (2006). Normative and informational influences in online political discussions. Communication Theory, 16, 47-74.

Ragas, M. W., \& Roberts, M. S. (2009). Communicating corporate social responsibility and brand sincerity: A case study of Chipotle Mexican Grill's 'Food with Integrity' program. International Journal of Strategic Communication, 3(4), 264-280.

Reid, S., Giles, H., \& Harwood, J. (2005). A self-categorization perspective on communication and intergroup relations. In J. Harwood, \& H. Giles (Eds.), Intergroup communication (pp. 241-263). New York: Peter Lang.

Reidenbach, R. E., \& Robin, D. P. (1988). Some initial steps toward improving the measurement of ethical evaluations of marketing activities. Journal of Business Ethics, 7(11), 871-879.

Rettab, B., Brik, A. B., \& Mellahi, K. (2009). A study of management perceptions of the impact of corporate social responsibility on organisational performance in emerging economies: the case of Dubai. Journal of Business Ethics, 89(3), 371-390. 
Rhee, J. W. (1997). Strategy and issue frame in election campaign coverage: A social cognitive account of framing effects. Journal of Communication, 47, 26-48.

Saiia, D. H., Carroll, A. B., \& Buchholtz, A. K. (2003). Philanthropy as strategy: When corporate charity begins at Home. Business and Society, 42, 169-201.

Sánchez, C. M. (2000). Motives for corporate philanthropy in El Salvador: Altruism and political legitimacy. Journal of Business Ethics, 27(4), 363-375.

Schlenker, B. R., \& Forsyth, D. R. (1977). On the ethics of psychological research. Journal of Experimental Social Psychology, 13(4), 369-396.

Schwepker, C. H., Jr., \& Good, D. J. (2011). Moral judgment and its impact on business-to-business sales performance and customer relationships. Journal of Business Ethics, 98(4), 609-625.

Semetko, H. A., \& Valkenburg, P. M. (2000). Framing European politics: A content analysis of press and television news. Journal of Communication, 50(2), 93-109.

Sen, S., \& Bhattacharya, C. B. (2001). Does doing good always lead to doing better? Consumer reactions to corporate social responsibility. Journal of Marketing Research, 38(2), 225-243.

Sharp, F. C. (1898). An objective study of some moral judgments. The American Journal of Psychology, 9(2), 198-234.

Shaw, B., \& Post, F. R. (1993). A moral basis for corporate philanthropy. Journal of Business Ethics, 12(10), 745-751.

Shen, F. (2004). Effects of news frames and schemas on individuals' issue interpretations and attitudes. Journalism \& Mass Communication Quarterly, 81, 400-416.

Shim, K. (2014). Impact of social media on power relations of Korean health activism. Media and Communication, 2(2), 72-83.

Shim, K., \& Yang, S. U. (2016). The effect of bad reputation: The occurrence of crisis, corporate social responsibility, and perceptions of hypocrisy and attitudes toward a company. Public Relations Review, 42, 68-78.

Singh, J., Salmones Sanchez, M. D. M. G., \& Bosque, I. R. (2008). Understanding corporate social responsibility and product perceptions in consumer markets: A crosscultural evaluation. Journal of Business Ethics, 80(3), 597-611.

Smith, N. (2003). Corporate social responsibility: Whether or how? California Management Review, 45, 52-76.

Springer, S. A., \& Harwood, J. (2015). The influence of episodic and thematic frames on policy and group attitudes: Mediational analysis. Human Communication Research, 41(2), 226-244.

Sprinkle, G. B., \& Maines, L. A. (2010). The benefits and costs of corporate social responsibility. Business Horizons, 53(5), 445-453. http://dx.doi.org/10.1016/j.bushor.2010.05.006.

Stolz, I. (2010). International and Intercultural Perspectives on Corporate Citizenship: A Meta-Synthesis (No. 4). SGOCI Working Paper.

Tanner, C., Medin, D. L., \& Iliev, R. (2008). Influence of deontological versus consequentialist orientations on act choices and framing effects: When principles are more important than consequences. European Journal of Social Psychology, 38(5), 757-769.

Vasella, D. (2003). Magic cancer bullet: how a tiny orange pill is rewriting medical history. Scranton, NY: Harper Business.

Vasquez, G. M., \& Taylor, M. (2001). Research perspectives on the public. In R. L. Heath (Ed.), Handbook of public relations (pp. 139-154). Thousand Oaks, CA: Sage.

Villa, D. (1992). Postmodernism and the public sphere. American Political Science Review, 86, 712-721.

Wagner, T., Lutz, R. J., \& Weitz, B. A. (2009). Corporate hypocrisy: Overcoming the threat of inconsistent corporate social responsibility perceptions. Journal of Marketing, 73, 77-91. 
Wang, A. (2007). Priming, framing, and position on corporate social responsibility. Journal of Public Relations Research, 19(2), 123-145.

Whalen, J., Pitts, R. E., \& Wong, J. K. (1991). Exploring the structure of ethical attributions as a component of the consumer decision model: The vicarious versus personal perspective. Journal of Business Ethics, 10(4), 285-293.

Yoon, Y., Gürhan-Canli, Z., \& Schwarz, N. (2006). The effect of corporate social responsibility (CSR) activities on companies with bad reputations. Journal of Consumer Psychology, 16(4), 377-390.

Zhang, R., Zhu, J., Yue, H., \& Zhu, C. (2010). Corporate philanthropic giving, advertising intensity, and industry competition level. Journal of Business Ethics, 94(1), 39-52.

Zoller, H. M. (2005). Health activism: Communication theory and action for social change. Communication Theory, 14(4), 341-364. 